\title{
Norfloxacin and N-Donor Mixed-Ligand Copper(II) Complexes: Synthesis, Albumin Interaction, and Anti-Trypanosoma cruzi Activity
}

\author{
Darliane A. Martins, ${ }^{1}$ Ligiane R. Gouvea, ${ }^{1}$ Gabriel S. Vignoli Muniz, ${ }^{2}$ Sonia R. W. Louro, ${ }^{2}$ \\ Denise da Gama Jaen Batista, ${ }^{3}$ Maria de Nazaré C. Soeiro, ${ }^{3}$ and Letícia R. Teixeira ${ }^{1}$ \\ ${ }^{1}$ Departamento de Química, Universidade Federal de Minas Gerais, 31270-901 Belo Horizonte, MG, Brazil \\ ${ }^{2}$ Departamento de Física, Pontifícia Universidade Católica do Rio de Janeiro, 22653-900 Rio de Janeiro, RJ, Brazil \\ ${ }^{3}$ Laboratório de Biologia Celular, Instituto Oswaldo Cruz, FIOCRUZ, 21040-360 Rio de Janeiro, RJ, Brazil \\ Correspondence should be addressed to Letícia R. Teixeira; lregina@qui.ufmg.br
}

Received 20 August 2015; Revised 2 January 2016; Accepted 3 January 2016

Academic Editor: Claudio Pettinari

Copyright ( 2016 Darliane A. Martins et al. This is an open access article distributed under the Creative Commons Attribution License, which permits unrestricted use, distribution, and reproduction in any medium, provided the original work is properly cited.

Copper(II) complexes with the first-generation quinolone antibacterial agent norfloxacin containing a nitrogen donor heterocyclic ligand 2,2' -bipyridine (bipy) or 1,10-phenanthroline (phen) were prepared and characterized by IR, EPR spectra, molar conductivity, and elemental analyses. The experimental data suggest that norfloxacin was coordinated to copper(II) through the carboxylato and ketone oxygen atoms. The interaction of the copper(II) complexes with bovine serum albumin (BSA) and human serum albumin (HSA) was investigated using fluorescence quenching of the tryptophan residues and copper(II) EPR spectroscopy. The results of fluorescence titration revealed that copper(II) complexes have a moderate ability to quench the intrinsic fluorescence of the albumins through a static quenching mechanism. EPR experiments showed that BSA and HSA Cu(II) sites compete with NOR for $\mathrm{Cu}$ (II)-bipy and $\mathrm{Cu}$ (II)-phen to form protein mixed-ligand complexes. Copper(II) complexes, together with the corresponding ligands, were evaluated for their trypanocidal activity in vitro against Trypanosoma cruzi, the causative agent of Chagas disease. The tests performed using bloodstream trypomastigotes showed that the $\mathrm{Cu}(\mathrm{II})-\mathrm{N}$-donor precursors and the metal complexes were more active than the free fluoroquinolone.

\section{Introduction}

Chagas disease, caused by the Trypanosoma cruzi protozoa, is an endemic parasitosis which affects about 8 million people in Latin America and leads to approximately 50000 deaths per year [1]. The only two available drugs for the treatment of Chagas disease are Nifurtimox and Benznidazole, but both exhibit grave side effects [2]. The limitations of the current chemotherapy for this illness justify the search for new drug candidates that could be effective and selective against this parasite but with lower toxicity and affordable costs.

Norfloxacin (NOR), 1-ethyl-6-fluoro-1,4-dihydro-4-oxo7-(1-piperazinyl)-quinoline-3-carboxylic acid, which was patented in 1978, is a synthetic and potent fluoroquinolone antibacterial agent [3]. NOR is used in the clinical treatment of many infections including prostate, skin, pulmonary, digestive, and urinary tract infections [4].

Metal complexes can be more active than their free ligands. Among the metal complexes so far investigated those containing $\mathrm{N}$-donor heterocyclic coligand have attracted a great deal of attention. Ligands like $2,2^{\prime}$-bipyridine (bipy) and 1,10-phenanthroline (phen) coordinated to the metal center in the bidentate mode have been proven to be more active than monodentate ligands like pyridine against microorganisms. Considering the nature of the $\mathrm{N}$-donor heterocyclic ligand the results found in the literature suggest that the inhibition of the growth of microorganisms increases in the order phen $>$ bipy $[5,6]$.

In the literature there are some examples of norfloxacin copper(II) complexes which contain nitrogen donor ligands 
[6-11]. However, few examples concerning the anti-T. cruzi activity of fluoroquinolone complexes can be found [12-15] as well as their albumins interaction studies using EPR.

In a recent research, our group studied the anti- $T$. cruzi activity of the sparfloxacin and levofloxacin copper(II) complexes containing $\mathrm{N}$-donor ligand and found that the presence of bipy and phen improves their biological activity. These complexes could bind to DNA, suggesting that the action mechanism could involve this molecule $[12,14]$.

In this work, we prepared two $\mathrm{Cu}(\mathrm{II})$-norfloxacin complexes containing $\mathrm{N}$-donor ligand, 2,2' -bipyridine or 1,10phenanthroline, and their anti-T. cruzi activity was tested. Given that the interaction of a drug with blood components can influence its bioavailability [16], the interaction of these complexes with bovine and human serum albumins (BSA and HSA) was also investigated, using the intrinsic fluorescence of the proteins and the EPR spectroscopy of the copper(II) ions.

Albumin is the most abundant serum protein, representing $52-60 \%$ of total blood plasma proteins. Human serum albumin (HSA) binds different classes of ligands at multiple sites. HSA provides a storage area for many compounds, affects pharmacokinetics of many drugs, restrains the orientation of some ligands providing metabolic modification, makes potential toxins nontoxic transporting them to disposal sites, accounts for most of the antioxidant capacity of human serum, and acts as NO-carrier [17].

Until recently, X-ray structural investigations of mammalian serum albumins have only concentrated on human serum albumin (HSA) (structures deposited in http://www.rcsb.org/), but in 2012 the crystal structures of serum albumins isolated from bovine, equine, and leporine blood plasma were reported to be deposited in RBSC PDB (http://www.rcsb.org/) [18]. BSA is one of the most extensively used proteins in protein research and is used as HSA substitute in many experiments, but it exhibits only $75.8 \%$ identity compared with HSA [18]. The HSA has two major binding regions, sites I and II, 585 amino acid residues, and only one tryptophan (Trp) located at position 214 in a hydrophobic pocket. BSA has two tryptophan residues (Trp 134 and $\operatorname{Trp} 212$ ), with $\operatorname{Trp} 134$ being located on the surface of the molecule and Trp 212 being located in a hydrophobic pocket [16].

The tryptophan's intrinsic fluorescence has been extensively used to study the interaction between drugs and proteins $[9,13,16,19]$. It is important, however, to have in mind that some binding sites are far from the Trp residues and no interaction will be detected. On the other hand, many drugs absorb radiation in the UV region of the electromagnetic spectrum and give rise to artifacts such as the inner filter effect, rather than quenching, and direct excitation of the fluorescence of certain drugs, rather than energy transfer. For this reason fluorescence quenching and energy transfer experiments must always follow optical absorption measurements, and careful corrections must be made.

\section{Experimental}

2.1. Materials. The BSA, HSA, norfloxacin, 2,2'-bipiridine, $\mathrm{CuCl}_{2} \cdot 2 \mathrm{H}_{2} \mathrm{O}$, and $\left[\mathrm{CuCl}_{2}\right.$ (phen) $]$ were purchased from
Sigma-Aldrich. All solvents were purchased from Merck.

$4 \times 10^{-6} \mathrm{~mol} \mathrm{~L}^{-1}$ BSA and HSA solutions were prepared in phosphate buffer at $\mathrm{pH}$ 7.4. $1.0 \times 10^{-3} \mathrm{~mol} \mathrm{~L}^{-1}$ stock solution of the $\mathrm{Cu}(\mathrm{II})$ complexes was prepared using $2.5 \%$ of dimethylsulfoxide (DMSO) and phosphate buffer at $\mathrm{pH}$ 7.4.

2.2. Apparatus. Elemental analyses were performed on a PerkinElmer 2004 CHN Elemental Analyzer. Molar conductivity measurements were performed in dimethylformamide (DMF) solutions, $1 \times 10^{-3} \mathrm{~mol} \mathrm{~L}^{-1}$ concentration, using a Quimis, model Q405M, conductivity meter. The IR spectra were acquired on a Mattson Instruments Galaxy 3000 spectrophotometer using $\mathrm{KBr}$ pellets. X-band electron paramagnetic resonance (EPR) spectra were obtained with a Bruker ESP300E spectrometer with a modulation frequency of $100 \mathrm{kHz}$ and a modulation amplitude of $1 \mathrm{mT}$. Frozen aqueous solutions of the complexes $\left(\sim 5 \times 10^{-4} \mathrm{~mol} \mathrm{~L}^{-1}\right)$ were measured at liquid $\mathrm{N}_{2}$ temperature $(77 \mathrm{~K})$ in Teflon ${ }^{\circledR}$ tubes with a $3 \mathrm{~mm}$ internal diameter.

2.3. Synthesis of the $\left[\mathrm{CuCl}_{2}(\right.$ bipy $\left.)\right]$ Precursor. The $\left[\mathrm{CuCl}_{2}\right.$ (bipy)] precursor was prepared using a method similar to that described in the literature [14], by dissolving equimolar amounts of $\mathrm{CuCl}_{2} \cdot 2 \mathrm{H}_{2} \mathrm{O}$ and $2,2^{\prime}$-bipyridine $(1.74 \mathrm{mmol})$ in about $20 \mathrm{~mL}$ of acetone. The mixture was allowed to stir and reflux for 24 hours and then was vacuum filtered. $\left[\mathrm{CuCl}_{2}\right.$ (bipy)] was subjected to elemental and infrared analysis.

2.4. Synthesis of the Complexes. $[\mathrm{CuCl}(\mathrm{NOR})($ bipy)$)] \mathrm{Cl}(\mathbf{1})$ was obtained by dissolving NOR $(0.31 \mathrm{mmol})$ in acetone $(30 \mathrm{~mL})$ which was gently heated and stirred. After cooling the solution to room temperature acetone solution of $\left[\mathrm{CuCl}_{2}\right.$ (bipy) $](0.31 \mathrm{mmol})$ was added. The mixture was stirred at room temperature for $24 \mathrm{~h}$. The solid which precipitated was filtered and washed with diethyl ether and dried in vacuum. $\left[\mathrm{CuCl}_{2}\right.$ (phen)(NOR)] (2) was prepared according to a similar method previously described by our group [12]. The complex was obtained by dissolving $0.31 \mathrm{mmol}$ of NOR in approximately $40 \mathrm{~mL}$ of acetone. After that $0.31 \mathrm{mmol}$ of $\left[\mathrm{CuCl}_{2}\right.$ (phen)] was dissolved in methanol which was added to the NOR solution. The mixture remained refluxing and stirring for about 24 hours. The solvent volume was reduced using a rotary evaporator. The precipitate formed was filtered under vacuum conditions, washed with diethyl ether, and dried. Figure 1 shows a coordination scheme for complexes 1 and 2.

[CuCl(bipy)(NOR)]Cl-2 $\mathrm{H}_{2} \mathrm{O}$ (1): Green solid. Yield: 73\%. Anal.: found, C 48.2, H 4.5, N 10.8. Calc. for $\mathrm{C}_{26} \mathrm{H}_{30} \mathrm{Cl}_{2} \mathrm{CuFN}_{5} \mathrm{O}_{5}, \mathrm{C}$ 48.3, H 4.7, N 10.8\%. Molar conductivity $\left(1 \times 10^{-3} \mathrm{~mol} \mathrm{~L}^{-1}, \mathrm{H}_{2} \mathrm{O}\right): 116.5 \mu \mathrm{S} \mathrm{cm}^{-1}$. IR $\left(\mathrm{cm}^{-1}\right): 1570 \mathrm{~s} \quad \nu(\mathrm{C}=\mathrm{O})$; $1630 \mathrm{~s} \quad v_{\text {as }}\left(\mathrm{COO}^{-}\right)$; $1396 \mathrm{~m} v_{s}\left(\mathrm{COO}^{-}\right)$. TG: mass loss (351-439 K): 10.5\% (found), $11.0 \%$ (calc).

$\left[\mathrm{CuCl}_{2}\right.$ (phen)(NOR)] $3 \mathrm{H}_{2} \mathrm{O}$ (2): Green solid. Yield: $90 \%$. Anal.: found, C 48.9, H 4.6, N 10.4. Calc. for 

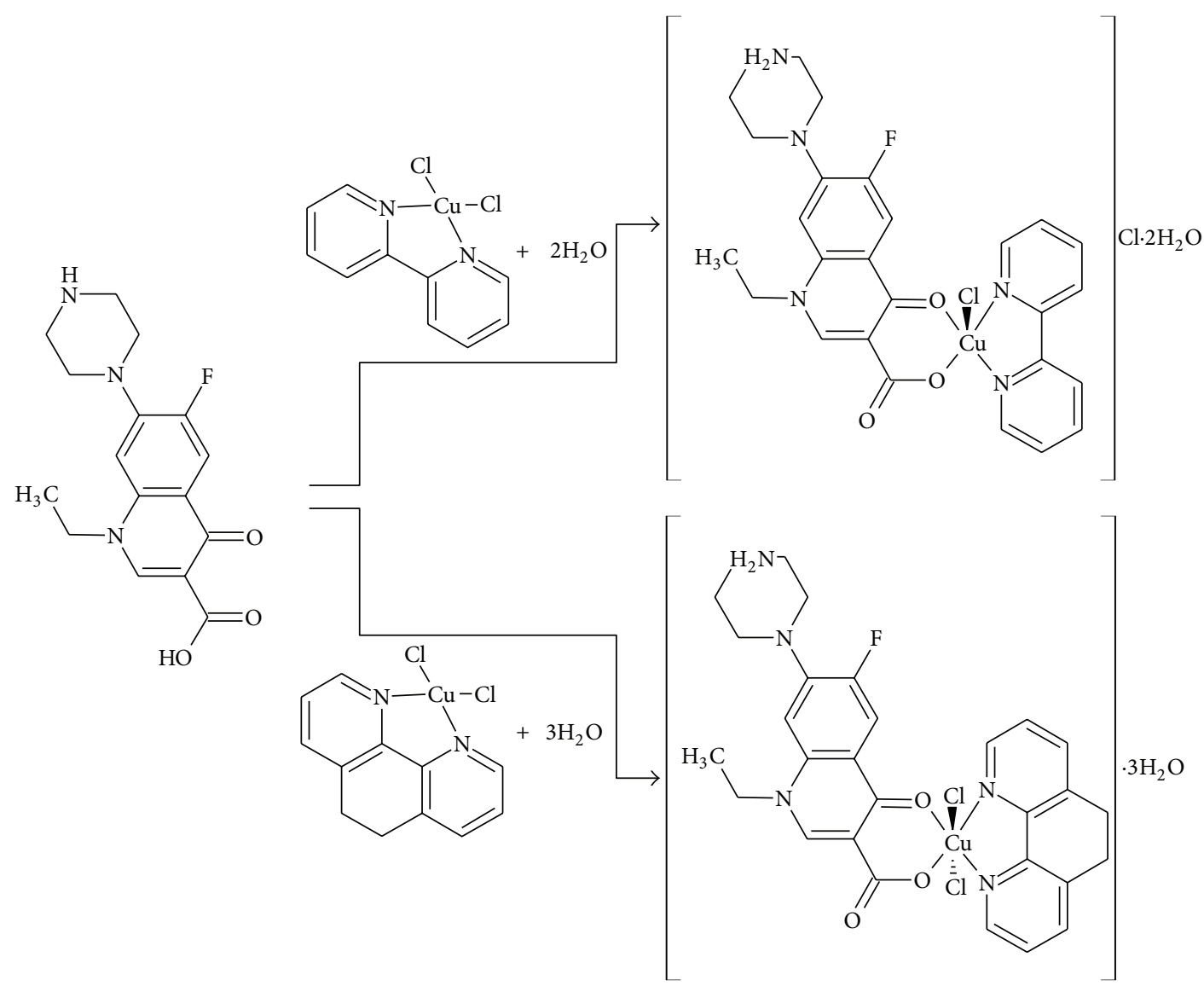

FIgURE 1: Coordination scheme for complexes $\mathbf{1}$ and $\mathbf{2}$.

$\mathrm{C}_{28} \mathrm{H}_{32} \mathrm{Cl}_{2} \mathrm{CuFN}_{5} \mathrm{O}_{6}, \mathrm{C} 48.9, \mathrm{H}$ 4.7, N 10.2\%. Molar conductivity $\left(1 \times 10^{-3} \mathrm{~mol} \mathrm{~L}^{-1}, \mathrm{DMF}\right): 22.4 \mu \mathrm{S} \mathrm{cm}^{-1}$. IR $\left(\mathrm{cm}^{-1}\right): 1580 \mathrm{~s} \quad \nu(\mathrm{C}=\mathrm{O})_{p} ; 1628 \mathrm{~s} \quad \nu_{\mathrm{as}}\left(\mathrm{COO}^{-}\right)$; $1386 \mathrm{~m} \mathrm{v}_{s}\left(\mathrm{COO}^{-}\right)$. TG: mass loss (351-434 K): 7.0\% (found), $7.8 \%$ (calc).

2.5. Parasites. Y strain of T. cruzi was used throughout the experiments [21]. Bloodstream forms were harvested by heart puncture from T. cruzi-infected Swiss mice at the peak of parasitemia [21].

2.6. Trypanocidal Analysis. For the in vitro analysis on trypomastigotes, the parasites were incubated at $310 \mathrm{~K}$ in the presence of increasing doses $(0-200 \mu \mathrm{M})$ of each compound diluted in Dulbecco's modified Eagle's medium which was supplemented with $5 \%$ fetal bovine serum and $1 \mathrm{mM} \mathrm{L-}$ glutamine (DMES) [22]. After $24 \mathrm{~h}$, death rates were determined by light microscopy through the direct quantification of live parasites using Neubauer chamber, and $\mathrm{EC}_{50}$ values (drug concentration which reduces $50 \%$ of the number of live parasites) were then calculated as reported $[2,23]$.

2.7. Mammalian Cell Cultures and Toxicity Assays. Primary cultures of embryonic cardiac cells (CM) were carried out from mice embryos taken from pregnant females (18-20 days gestation). Pregnant animals were euthanized and the hearts' embryos collected. Then the ventricles were subjected to successive steps of mechanical and enzymatic dissociation $\left(0.05 \%\right.$ trypsin and $0.01 \%$ collagenase for $\left.5 \mathrm{~min} / 37^{\circ} \mathrm{C}\right)$. After purification, the $\mathrm{CM}$ were seeded at a density of $0.05 \times$ $10^{6}$ cell/well into 96-well microplates, containing gelatincoated cover slips and sustained in Dulbecco's modified Eagle's medium, which was supplemented with 5\% fetal bovine serum, $2.5 \mathrm{mM} \mathrm{CaCl}_{2}, 1 \mathrm{mM} \mathrm{L}$-glutamine, and $2 \%$ chicken embryo extract (DMEM) [24]. All procedures were carried out in accordance with the guidelines established by the FIOCRUZ Committee of Ethics for the Use of Animals (License LW-16/14). All the cultures were maintained at $37^{\circ} \mathrm{C}$ in an atmosphere of $5 \% \mathrm{CO}_{2}$, and the assays were run at least three times in duplicate. In order to rule out the toxic effects of the compounds on mammalian host cells, uninfected CMs were incubated for $24 \mathrm{~h}$ at $37^{\circ} \mathrm{C}$ in the presence or absence of the compounds (up to $200 \mu \mathrm{M}$ ) diluted in DMEM, and then their morphology was evaluated by light microscopy and the cell viability was measured by the MTT colorimetric assay [25]. As control, only vehicle was used. The absorbance was measured at $490 \mathrm{~nm}$ wavelength with a spectrophotometer (VERSAmax Tunable, Molecular Devices, USA) allowing the determination of $\mathrm{LC}_{50}$ values (drug concentration which reduces $50 \%$ of cellular viability) and the respective selective indexes $\left(\mathrm{SI}=\mathrm{LC}_{50} / \mathrm{EC}_{50}\right)$. 
2.8. Albumin Binding Studies. Steady state fluorescence measurements were performed on a Varian-Agilent Cary Eclipse or a PTI QM1 fluorescence system. UV-Vis absorption spectra were obtained with an Agilent diode array spectrophotometer model 8452A. Fluorescence lifetimes were measured using IBH-Horiba-Jobin Yvon TCSPC system. NanoLEDs with $1.0 \mathrm{~ns}$ nominal pulse duration and $1 \mathrm{MHz}$ repetition rate were used as light sources for exciting the intrinsic HSA or BSA fluorescence $(283 \mathrm{~nm})$ and NOR fluorescence (330 nm).

Quenching measurements of albumin fluorescence were taken in $3 \mathrm{~mL}$ of BSA or HSA $\left(4 \times 10^{-6} \mathrm{~mol} \mathrm{~L}^{-1}\right)$ in phosphate buffer $10 \mathrm{mM}$ at $\mathrm{pH}$ 7.4. The albumin solutions were titrated by successive additions of the complex stock solutions. The fluorescence emission spectra of BSA and HSA were measured using an excitation wavelength of $290 \mathrm{~nm}$. Experiments were performed at ambient temperature $(296 \mathrm{~K})$ and $\mathrm{pH} 7.4$.

For the EPR studies of the interaction of the complexes with HSA and BSA, equimolar solutions $\left(0.5 \times 10^{-3} \mathrm{~mol} \mathrm{~L}^{-1}\right)$ of BSA or HSA with each $\mathrm{Cu}$ (II) complex were prepared in $0.020 \mathrm{~mol} \mathrm{~L}^{-1}$ phosphate buffer at $\mathrm{pH}$ 7.4. EPR spectra were obtained at $77 \mathrm{~K}$.

\section{Results and Discussion}

3.1. Microanalyses and Molar Conductivity Studies. Microanalyses and molar conductivity data suggested the formation of $\left[\mathrm{CuCl}(\right.$ bipy)(NOR) $] \mathrm{Cl} \cdot 2 \mathrm{H}_{2} \mathrm{O}$ (1) and $\left[\mathrm{CuCl}_{2}\right.$ (phen)(NOR)] $3 \mathrm{H}_{2} \mathrm{O}(\mathbf{2})$, in which the fluoroquinolone NOR coordinated as a neutral bidentate ligand. The thermogravimetric data confirmed the presence of hydration water molecules in the complexes' structures. Complex $\mathbf{1}$ exhibited a pentacoordinated structure in keeping with most examples found in the literature for $\mathrm{Cu}$ (II)-fluoroquinolone$\mathrm{N}, \mathrm{N}$-donor complexes. These presented a square pyramidal geometry which was confirmed by X-ray crystallographic structures [7-10, 26]. Complex 2 was hexacoordinated and presented an octahedral geometry which is not common for this type of complexes. In the literature there are examples of X-ray crystallographic structures for hexacoordinated fluoroquinolone complexes without N,N-donor [27, 28].

3.2. Infrared Spectral Studies. The infrared spectrum of free norfloxacin (NOR) exhibited a band of $1730 \mathrm{~cm}^{-1}$ which was assigned to the valence vibration of the carboxylic stretch $\nu(\mathrm{C}=\mathrm{O})_{\text {carb }}$ and a band at $1616 \mathrm{~cm}^{-1}$ which was assigned to pyridone stretch $\nu(\mathrm{C}=\mathrm{O})_{p}$ [29]. The most typical vibrations that were characteristic of the coordination type of quinolones were used in the metal-quinolone complex characterization. In the IR spectra of complexes $\mathbf{1}$ and $\mathbf{2}$ the absorption of the $v(\mathrm{C}=\mathrm{O})_{\text {carb }}$ vibration was not observed, due to the deprotonation of the carboxylic group, indicating that this group was involved in coordination. Two new very strong characteristic bands appeared at 1630 and $1628 \mathrm{~cm}^{-1}$ and 1396 and $1386 \mathrm{~cm}^{-1}$ and were assigned to $\nu\left(\mathrm{COO}^{-}\right)$asymmetric and symmetric stretching vibrations for complexes $\mathbf{1}$ and $\mathbf{2}$, respectively, whereas $\nu(\mathrm{C}=\mathrm{O})_{p}$ was shifted from 1616 to 1570 and $1580 \mathrm{~cm}^{-1}$ upon coordination for $\mathbf{1}$ and $\mathbf{2}$, respectively.
TABLE 1: EPR parameters of the $\mathrm{Cu}(\mathrm{II})$ complexes.

\begin{tabular}{lcccc}
\hline Powder (room temperature) & $g_{\perp}$ & $g_{\|}$ & $g_{\text {binuc }}$ & $D$ (gauss) \\
\hline$\left[\mathrm{CuCl}_{2}\right.$ (phen) $]$ & 2.074 & 2.292 & & \\
{$\left[\mathrm{CuCl}(\right.$ bipy)(NOR) $] \mathrm{Cl} \cdot 2 \mathrm{H}_{2} \mathrm{O}(\mathbf{1})$} & 2.068 & 2.250 & 2.08 & 425 \\
{$\left[\mathrm{CuCl}_{2}\right.$ (phen)(NOR) $] \cdot 3 \mathrm{H}_{2} \mathrm{O}(\mathbf{2})$} & 2.08 & & & \\
\hline Aqueous solution $(77 \mathrm{~K})$ & $g_{\perp}$ & $g_{\|}$ & $g_{\text {binuc }}$ & $D$ (gauss) \\
\hline$\left[\mathrm{CuCl}_{2}\right.$ (phen) $]$ & 2.08 & 2.22 & & \\
{$\left[\mathrm{CuCl}_{(\text {bipy) }(\mathrm{NOR})] \mathrm{Cl} \cdot 2 \mathrm{H}_{2} \mathrm{O}(\mathbf{1})}\right.$} & & 2.08 & 490 \\
{$\left[\mathrm{CuCl}_{2}\right.$ (phen)(NOR) $] \cdot 3 \mathrm{H}_{2} \mathrm{O}(\mathbf{2})$} & & & 2.07 & 505 \\
\hline
\end{tabular}

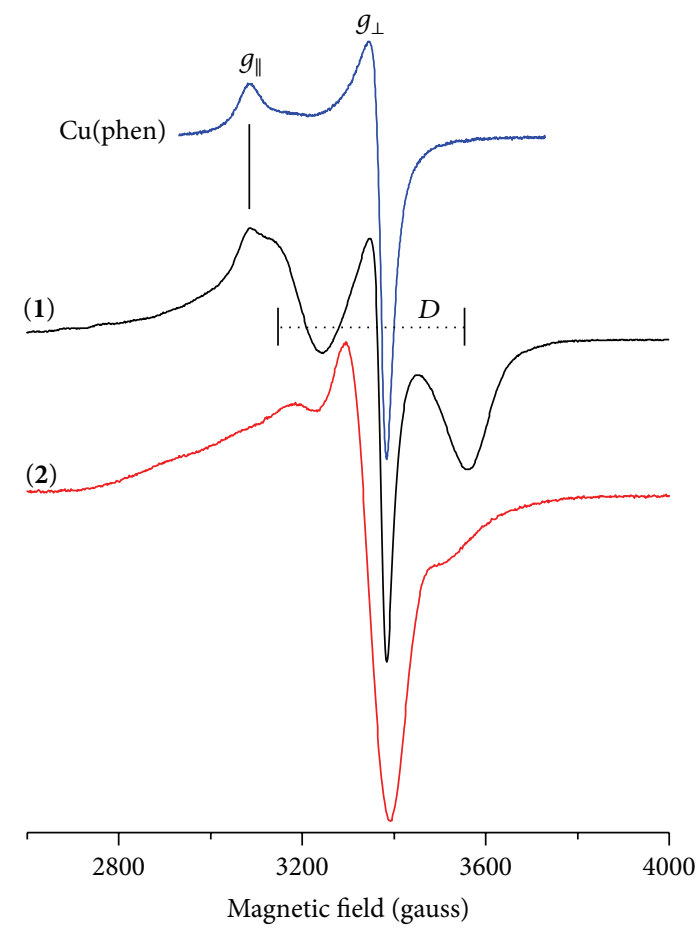

FIgURE 2: X-band EPR spectra of $\left[\mathrm{CuCl}_{2}\right.$ (phen)] and complexes 1 and $\mathbf{2}$ (powder, ambient temperature).

The $\Delta=v\left(\mathrm{COO}^{-}\right)_{\text {asym }}-v\left(\mathrm{COO}^{-}\right)_{\text {sym }}$ difference is a useful characteristic for determining the coordination mode of the quinolone ligands. $\Delta$ values for complexes $\mathbf{1}$ and $\mathbf{2}$ were 234 and $242 \mathrm{~cm}^{-1}$, respectively, indicating a monodentate coordination mode of the NOR carboxylato group [30]. The overall changes of the IR spectra suggested that the norfloxacin ligand was coordinated to $\mathrm{Cu}$ (II) via the pyridone and one carboxylate oxygen in the neutral zwitterionic form.

3.3. EPR Spectra of the Copper Complexes. Room temperature $\mathrm{X}$-band EPR spectra of $\mathbf{1}$ and $\mathbf{2}$ complexes powder samples are presented in Figure 2 and the parameters are in Table 1. The spectrum of $\left[\mathrm{CuCl}_{2}\right.$ (phen)] is also presented for comparison, which is characteristic of mononuclear copper complexes with axial symmetry, and lacks the hyperfine splitting at room temperature, as commonly observed in concentrated solid $\mathrm{Cu}$ (II) complexes [14]. Complex $\mathbf{1}$ is a mixture of mononuclear and binuclear $\mathrm{Cu}(\mathrm{II})$ complexes. Its EPR spectrum is a superposition of spectrum similar to $\mathrm{Cu}$ (phen) spectrum and 


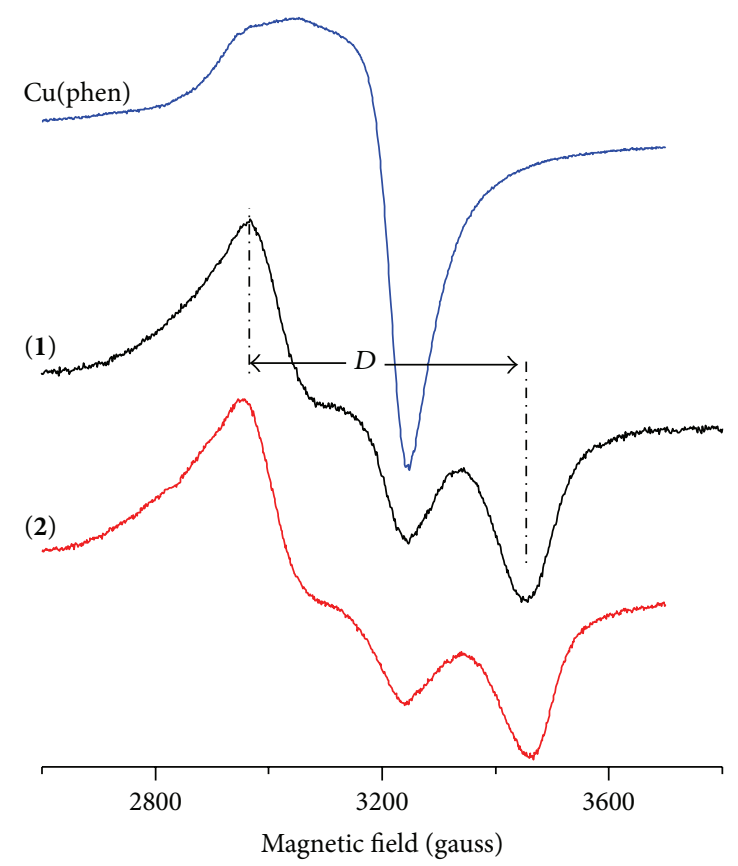

FIGURE 3: EPR spectra of $\left[\mathrm{CuCl}_{2}\right.$ (phen)] and complexes $\mathbf{1}$ and $\mathbf{2}$ in water $\left(\sim 10^{-3} \mathrm{~mol} \mathrm{~L}^{-1}\right)$ at $77 \mathrm{~K}$.

a well resolved doublet, associated with the triplet state $(S=1$, $\left.\Delta m_{S}= \pm 1\right)$ of binuclear complexes $[14,31,32]$.

The room temperature EPR spectrum of complex 2 is a superposition of a very broad ( $\sim 330$ gauss) component due to strong dipole-dipole interactions superimposed to a 100 gauss line width component at the $g_{\perp}$ region.

The EPR spectra of $\left[\mathrm{CuCl}_{2}\right.$ (phen)] and complexes $\mathbf{1}$ and 2 in water at $77 \mathrm{~K}$ are presented in Figure 3 (parameters are in Table 1). It can be observed that the spectra of the mixedligand complexes are almost exclusively due to binuclear species, with a small fraction of mononuclear species, while $\left[\mathrm{CuCl}_{2}\right.$ (phen)] presents a mononuclear spectrum where the absence of hyperfine splitting suggests aggregation leading to exchange [12].

The distance between the two $\mathrm{Cu}(\mathrm{II})$ ions can be estimated from the zero field splitting parameter $D$. The average distance $r$ between the two coupled unpaired electrons can be calculated by using the following equation:

$$
D=\frac{3}{2} \frac{g \beta}{r^{3}}=1.39 \times 10^{4} \frac{g}{r^{3}},
$$

for $D$ in gauss and $r$ is in angstroms [33]. The calculated distance $r$ for the binuclear complexes $\mathbf{1}$ and $\mathbf{2}$ is $3.9 \AA$. This distance is similar to those obtained for other $\mathrm{Cu}(\mathrm{II})$ binuclear complexes $[12,34,35]$.

3.4. Anti-Trypanosoma cruzi Activity. The effect of all the complexes, precursors, and benznidazole, the reference drug, against bloodstream trypomastigote forms of T. cruzi (Y strain), expressed as $\mathrm{EC}_{50}$, and their corresponding selectivity index (SI, ratio between $\mathrm{LC}_{50}$ and $\mathrm{EC}_{50}$ values, Table 2) were evaluated.
TABLE 2: Activity (mean \pm SD) and selectivity index (SI) of the compounds and benznidazole upon bloodstream trypomastigotes (BT) forms of T. cruzi (Y strain) in vitro ( $24 \mathrm{~h}$ of incubation at $37^{\circ} \mathrm{C}$ ).

\begin{tabular}{lcc}
\hline Compound & $\mathrm{EC}_{50}(\mu \mathrm{M})$ & $\mathrm{SI}$ \\
\hline Norfloxacin (NOR) & $126 \pm 30$ & $>1.25$ \\
{$[\mathrm{CuCl}$ (bipy)(NOR) $] \mathrm{Cl} \cdot 2 \mathrm{H}_{2} \mathrm{O}(\mathbf{1})$} & $16 \pm 4$ & 4 \\
{$\left[\mathrm{CuCl}_{2}\right.$ (phen)(NOR)] $3 \mathrm{H}_{2} \mathrm{O}(2)$} & $4.4 \pm 1.4$ & 2.68 \\
{$\left[\mathrm{CuCl}_{2} \text { (bipy) }\right]^{*}$} & $14 \pm 7$ & 4.5 \\
{$\left[\mathrm{CuCl}_{2} \text { (phen) }\right]^{*}$} & $7 \pm 5$ & $<4$ \\
{$\left[\mathrm{CuCl}_{2}\right.$ (NOR) $]$} & $78 \pm 12$ & 0.8 \\
$\mathrm{CuCl}_{2}{ }^{*}$ & $83 \pm 3$ & 6 \\
Benznidazole & $13 \pm 2$ & 77 \\
\hline
\end{tabular}

SD: standard deviation of multiple experimental measurements.

SI: selective index: ratio between $\mathrm{LC}_{50} / \mathrm{EC}_{50}$ values.

$\mathrm{LC}_{50}$ : drug concentration which reduces the viability of mammalian cell by $50 \%$.

$\mathrm{EC}_{50}$ : drug concentration which reduces the number of the parasites by $50 \%$. ${ }^{*}$ Data published in Martins et al., 2012 [14].

The free norfloxacin (NOR) and $\mathrm{CuCl}_{2}$ exerted a low trypanocidal effect against bloodstream trypomastigotes, exhibiting an $\mathrm{EC}_{50}$ value of $126 \pm 30$ and $83 \pm 3 \mu \mathrm{M}$, respectively. The same could be observed when trypomastigotes were exposed to $\left[\mathrm{CuCl}_{2} \mathrm{NOR}\right]$, which showed an $\mathrm{EC}_{50}$ value of $78 \pm 12 \mu \mathrm{M}$ (Table 2).

The complexation of $\mathrm{Cu}(\mathrm{II})-\mathrm{NOR}$ to $2,2^{\prime}$ bipyridine (bipy) improves the anti- $T$. cruzi activity. $\left[\mathrm{CuCl}_{2}\right.$ (bipy)(NOR)] exhibited an $\mathrm{EC}_{50}$ value of $16 \pm 4 \mu \mathrm{M}$ and the $\left[\mathrm{CuCl}_{2}\right.$ (bipy)] precursor exhibited an $\mathrm{EC}_{50}$ value of the same order: $\mathrm{EC}_{50}=14 \pm 7 \mu \mathrm{M}$. Therefore we suggest that the activity presented by complex 1 can be related to the $\left[\mathrm{CuCl}_{2}\right.$ (bipy)] precursor that showed similar activity to the reference drug, benznidazole $\left(\mathrm{EC}_{50}=13 \pm 2 \mu \mathrm{M}\right)$.

$\left[\mathrm{CuCl}_{2}\right.$ (phen) $]$ and $\left[\mathrm{CuCl}_{2}\right.$ (phen)(NOR)] revealed themselves as the most active compounds, exhibiting $\mathrm{EC}_{50}$ values of $7 \pm 5$ and $4.4 \pm 1.4 \mu \mathrm{M}$, respectively. These compounds were 2-3 times more active than benznidazole, being the most promising anti-T. cruzi agents.

The relative toxicity of the free bases and their metal complexes was evaluated in uninfected CM. After $24 \mathrm{~h}$ of treatment, all compounds induced loss of cellular viability and cell contractility in doses $>12 \mu \mathrm{M}$ (Table 2) and thus the corresponding low SI values were suggestive of a generic toxicity.

3.5. Albumin Binding Studies. In this section, the quenching of BSA and HSA fluorescence by $\mathrm{Cu}(\mathrm{II})$ ions, $\mathrm{Cu}(\mathrm{II})$-bipy, $\mathrm{Cu}(\mathrm{II})$-phen, and complexes $\mathbf{1}$ and $\mathbf{2}$ was monitored. All the UV absorption and emission spectra were registered. The fluorescence decay curves with excitation at $283 \mathrm{~nm}$ and emission at $340 \mathrm{~nm}$ were obtained in the absence of the quenchers, at an intermediary and at the final quencher concentration. The raw data are available in Supplementary Material available online at http://dx.doi.org/10.1155/2016/5027404. The fluorescence intensity was attenuated by absorption of the incident and emitted light. These attenuation effects called primary and secondary inner filter effects, respectively, do 
TABLE 3: Stern-Volmer constants values, $K_{\mathrm{SV}}$, for the titration of HSA and BSA with the copper complexes at $296 \mathrm{~K}$ (standard error, $0.2 \times$ $10^{4} \mathrm{~L} \mathrm{~mol}^{-1}$ ).

\begin{tabular}{|c|c|c|c|c|}
\hline \multirow{2}{*}{ Compound } & \multicolumn{2}{|c|}{ HSA } & \multicolumn{2}{|c|}{ BSA } \\
\hline & $K_{\mathrm{SV}}\left(\mathrm{L} \mathrm{mol}^{-1}\right)$ & $R^{2}$ & $K_{\mathrm{SV}}\left(\mathrm{L} \mathrm{mol}^{-1}\right)$ & $R^{2}$ \\
\hline $\mathrm{Cu}(\mathrm{II})$ & $2.9 \times 10^{4}$ & 0.998 & $3.5 \times 10^{4}$ & 0.998 \\
\hline$\left[\mathrm{CuCl}_{2}\right.$ (bipy) $]$ & $5.0 \times 10^{4}$ & 0.955 & $3.1 \times 10^{4}$ & 0.955 \\
\hline$[\mathrm{CuCl}($ bipy $)(\mathrm{NOR})] \mathrm{Cl} \cdot 2 \mathrm{H}_{2} \mathrm{O}(\mathbf{1})$ & $5.8 \times 10^{4}$ & 0.987 & $3.0 \times 10^{4}$ & 0.987 \\
\hline$\left[\mathrm{CuCl}_{2}\right.$ (phen) $]$ & $5.1 \times 10^{4}$ & 0.993 & $3.5 \times 10^{4}$ & 0.993 \\
\hline$\left[\mathrm{CuCl}_{2}\right.$ (phen)(NOR) $] \cdot 3 \mathrm{H}_{2} \mathrm{O}(2)$ & $4.9 \times 10^{4}$ & 0.989 & $3.7 \times 10^{4}$ & 0.989 \\
\hline
\end{tabular}

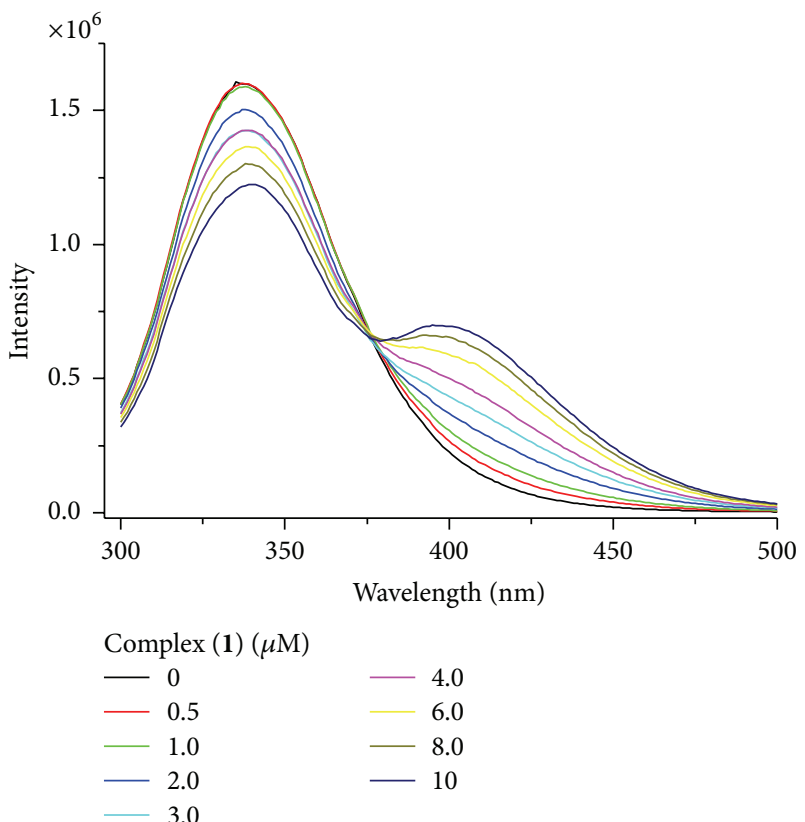

FIGURE 4: Fluorescence spectra of BSA $\left(4 \mu \mathrm{mol} \mathrm{L}^{-1}\right)$ in the absence and presence of increasing amounts of $[\mathrm{CuCl}($ bipy $)(\mathrm{NOR})] \mathrm{Cl}(\mathbf{1})$.

not contain molecular information. The fluorescence spectra were corrected using the following expression [36]:

$$
F_{\text {corr }}=F_{\text {obs }} 10^{\left[\left(A_{\mathrm{ex}}+A_{\mathrm{em}}\right) \ell / 2\right]},
$$

where $F_{\text {corr }}$ and $F_{\text {obs }}$ are the corrected and observed fluorescence intensity, $A_{\mathrm{ex}}$ and $A_{\mathrm{em}}$ are the absorbance at the excitation and emission wavelengths, respectively, and $\ell$ is the optical path in $\mathrm{cm}$. This expression assumes that the absorbing and emitting portion of the sample is localized at the center of the cuvette and was observed to be a good approximation for absorbances less than 0.5 .

Figure 4 shows an example of corrected fluorescence spectra obtained by titrating BSA with complex 1, with excitation at $290 \mathrm{~nm}$. BSA has a strong fluorescence emission peak at $338 \mathrm{~nm}$ due to the two Trp residues, while HSA (supplementary material) has a fluorescence emission peak at $336 \mathrm{~nm}$ due to the single Trp 214 residue. The fluorescence of tyrosine residues is negligible with the used excitation wavelength.

The fluorescence intensity of BSA and HSA was observed to decrease in the presence of $\mathrm{Cu}$ (II) and all four complexes
(Figure 5), indicating that $\mathrm{Cu}(\mathrm{II})$ is an important quenching unit. Figure 5 shows the Stern-Volmer plots for the quenching of HSA and BSA fluorescence by the complexes. It can be observed that at low concentrations there is no quenching, suggesting a high affinity site for $\mathrm{Cu}(\mathrm{II})$ and complexes which does not interact with the Trp residue(s). For complex concentrations greater than 2 or $4 \times 10^{-6} \mathrm{~mol} \mathrm{~L}^{-1}$, the plots are linear, suggesting interaction at a second site.

Quenching of a fluorophore by a drug can occur by a static or dynamic process. Static or dynamic quenching at a single site can be described by the Stern-Volmer equation [36]:

$$
\frac{F_{0}}{F}=1+K_{\mathrm{SV}}[Q]
$$

where $F_{0}$ and $F$ are the fluorescence intensities of albumins in the absence and presence of complexes, respectively. [Q] is the quencher concentration, and $K_{\mathrm{SV}}$ is the Stern-Volmer quenching constant, which is related to the bimolecular collisional process in dynamic quenching but is the association constant in static quenching. Stern-Volmer constants were obtained for the linear region of the plots (Table 3).

The Stern-Volmer constant, $K_{\mathrm{SV}}$, was of the order of $10^{4} \mathrm{~L} \mathrm{~mol}^{-1}$ indicating that the complexes have a moderated interaction with HSA and BSA.

Both static quenching and dynamic quenching require molecular contact between the fluorophore and quencher. In the case of collisional quenching, the quencher must diffuse to the fluorophore during the lifetime of the excited state. Upon contact, the fluorophore returns to the ground state without emission of a photon and the lifetime of the excited state changes. In static quenching a nonfluorescent complex is formed between the fluorophore and the quencher, which does not contribute to fluorescence, and the lifetime does not change [36]. In order to distinguish static quenching from dynamic quenching, the fluorescence decays and lifetimes of HSA and BSA were measured by using the time-correlated single photon counting (TCSPC) technique. It was observed that the decay profile was not influenced by the presence of the $\mathrm{Cu}$ (II) ions or $\mathrm{Cu}$ (II) complexes. It is therefore concluded that a nonfluorescent ground state complex is formed.

Resonance energy transfer (RET) also reduces the fluorescence intensity and differs from static or dynamic quenching because it does not require molecular contact. The drug must be an acceptor for the donor molecule (Trp residue, in this case); that is, the absorption spectrum of the drug must overlap with the Trp emission spectrum. NOR is a good candidate for Trp acceptor (see absorption spectrum in supplementary 

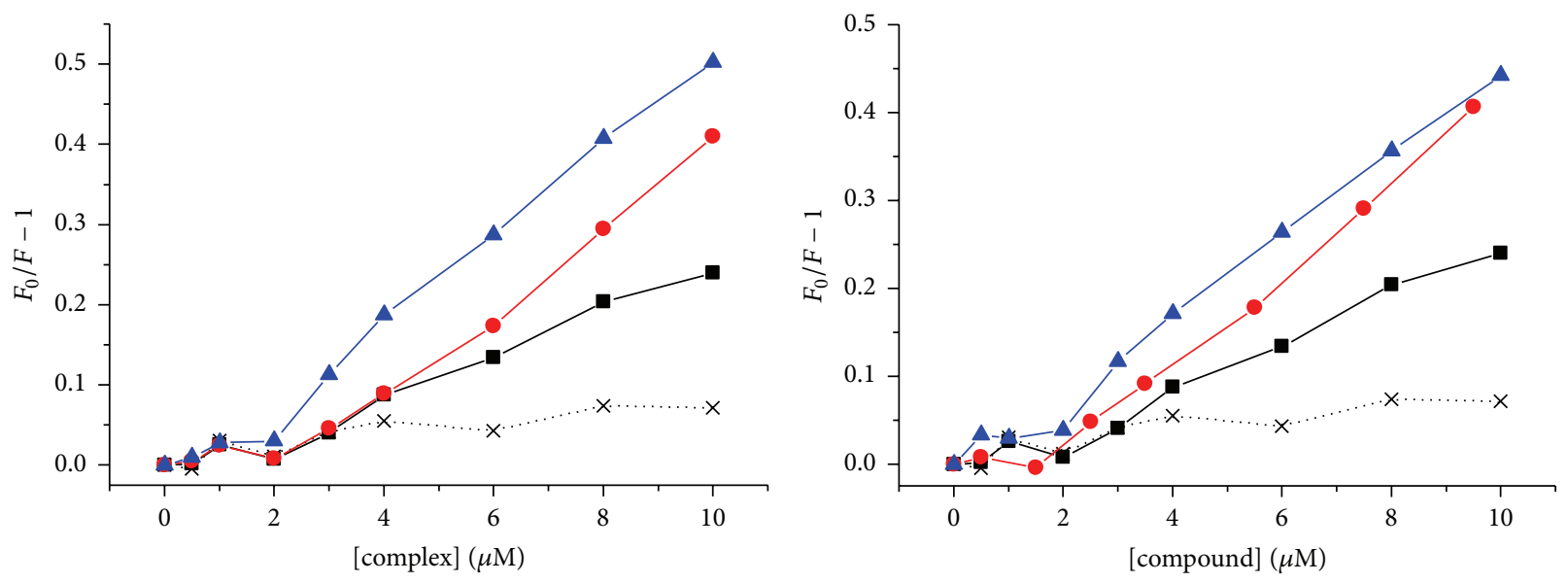

HSA
$\cdots \times \cdot \mathrm{NOR}$
$\rightarrow \mathrm{Cu}(\mathrm{II}) \quad-\left[\mathrm{CuCl}_{2}\right.$ (bipy) $]$

HSA

$\cdots \times$ NOR $\rightarrow\left[\mathrm{CuCl}_{2}\right.$ (phen) $]$

$\rightarrow \mathrm{Cu}(\mathrm{II}) \quad 2$

(a)

(b)
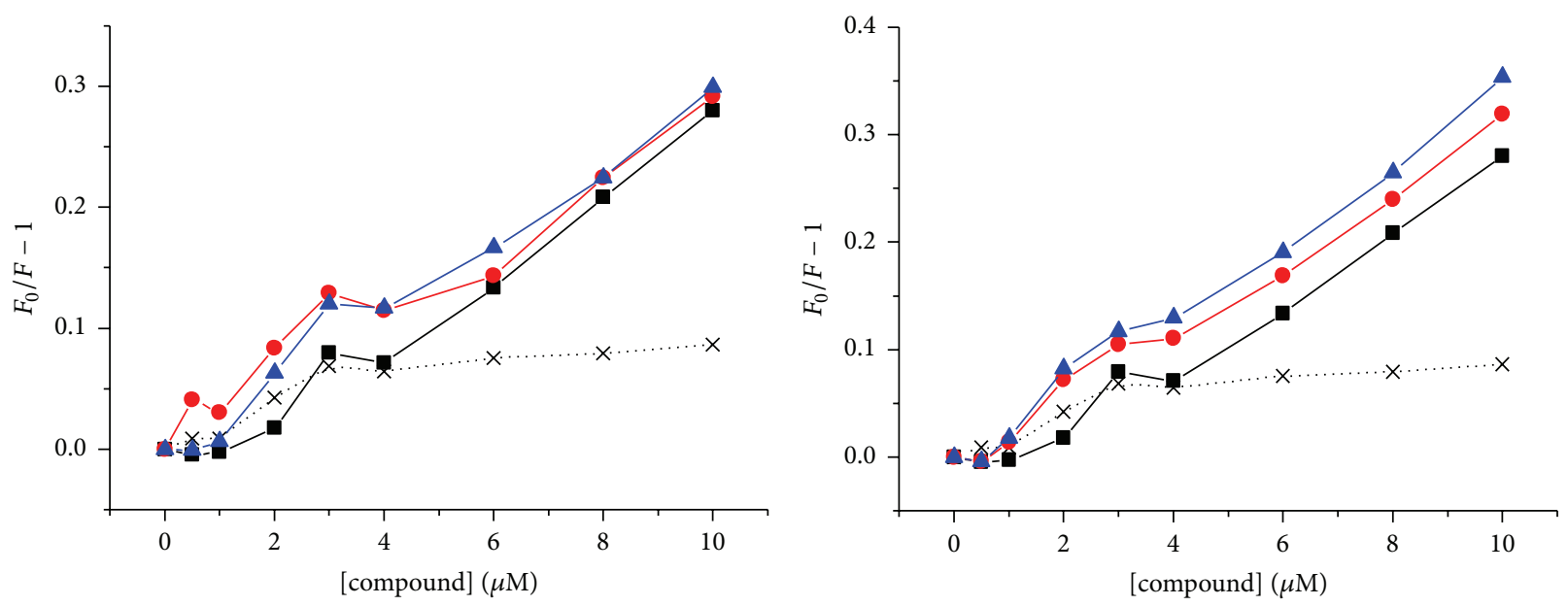

$\mathrm{BSA}$
$\because \times \cdot \mathrm{NOR}$
$\rightarrow-\mathrm{Cu}(\mathrm{II})$

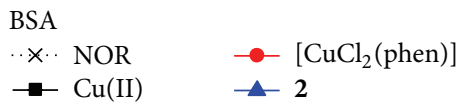

(c)

(d)

FIGURE 5: Stern-Volmer plots for the quenching of albumins' intrinsic fluorescence by the copper complexes: (a) HSA-complex (1), (b) HSAcomplex (2), (c) BSA-complex (1), and (d) BSA-complex (2). Control results of the effects of NOR and Cu(II) are also presented. $F_{0}$ and $F$ are the fluorescence intensities at the peak in the absence and presence of the complexes. HSA and BSA concentrations equal to $4.0 \times 10^{-6} \mathrm{~mol} \mathrm{~L} \mathrm{~L}^{-1}$; temperature: $296 \mathrm{~K}$.

material), but it was observed that the fluorescence increase around $408 \mathrm{~nm}$ (see Figure 4) has the same magnitude as the direct excitation of NOR. Furthermore, the absence of lifetime modifications eliminates the suggestion of RET.

Živec et al. [9] found that $1: 2 \mathrm{Cu}: \mathrm{NOR}$ and $1: 1: 1$ $\mathrm{Cu}$ : NOR: phen complexes exhibit good binding propensity to human or bovine serum albumin with binding constants of the same order of magnitude as these obtained by us and shown in Table 3. However, they did not correct their quenching results for the inner filter effect and their binding constants are overestimated.

3.6. Albumin Binding of the Cu(II) Complexes: EPR Studies. The human and bovine serum albumins have at least two
$\mathrm{Cu}$ (II) binding sites (denoted as $\mathrm{Cu}_{(1)}$ and $\mathrm{Cu}_{(2)}$ ) including a strong $\mathrm{N}$-terminal site that binds $\mathrm{Cu}(\mathrm{II})$ in a square-planar geometry via four nitrogen ligands $\left(\mathrm{Cu}_{(1)}\right)$, which is similar in both human and bovine albumins [37-39]. This highest affinity binding site for the metal is formed by $\alpha-\mathrm{NH}_{2} \mathrm{~N}$ atom, $\mathrm{N}$ atoms of the first two peptide bonds, and $\mathrm{N}_{3}$ atom of His3. This $\mathrm{N}$-terminal site is fairly specific for transition metal ions and binds $\mathrm{Cu}(\mathrm{II})$ and $\mathrm{Ni}(\mathrm{II})$ in forms that will not generate reactive species [17].

Cys34 is the only cysteine with a free sulfhydryl group which does not participate in a disulfide linkage with any external ligand [40] and is involved in the second copper binding site. There is evidence that the second $\mathrm{Cu}$ (II) binds to deprotonated Cys34 residue [41]. 
TABLE 4: EPR parameters obtained from simulated $\mathrm{Cu}$ (II) complexes interaction with HSA and BSA.

\begin{tabular}{lccc}
\hline & \multicolumn{3}{c}{ Site 1 } \\
& $g_{\perp}$ & $g_{\|}$ & $A_{\|}(\mathrm{MHz})$ \\
\hline $\mathrm{Cu}$ (BSA) & 2.046 & 2.190 & $601(196 \mathrm{G})$ \\
$\mathrm{Cu}$ (bipy)(HSA) & 2.052 & 2.190 & $603(197 \mathrm{G})$ \\
\hline & \multicolumn{3}{c}{ Sites 2 and $2^{\prime}$} \\
& $g_{\perp}$ & $g_{\|}$ & $A_{\|}(\mathrm{MHz})$ \\
\hline$\left[\mathrm{CuCl}_{2}\right.$ (phen) $]$ & 2.074 & 2.292 & $479(155 \mathrm{G})$ \\
$\mathrm{Cu}(\mathrm{BSA})$ site 2 & 2.070 & 2.299 & $505(157 \mathrm{G})$ \\
$\mathrm{Cu}$ (bipy)(HSA) site 2' & 2.062 & 2.265 & $528(167 \mathrm{G})$ \\
\hline
\end{tabular}

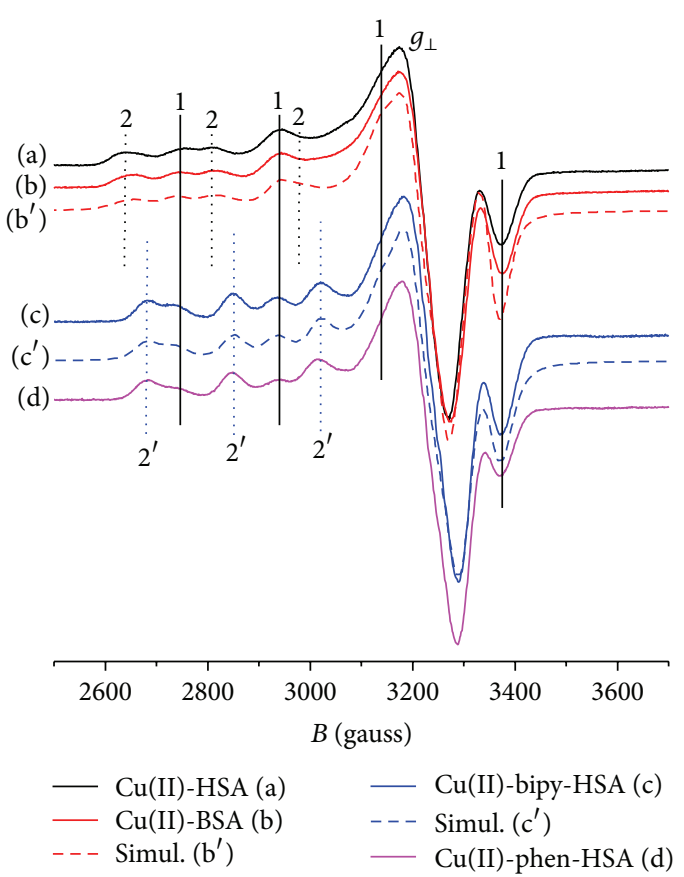

FIgURE 6: X-band EPR spectra for HSA and BSA Cu(II) complexes ((a) and (b), resp.) and for $\mathrm{Cu}(\mathrm{II})$-bipy and $\mathrm{Cu}$ (II)-phen complexes with HSA ((c) and (d), resp.). Experimental conditions: $\mathrm{Cu}$, HSA, and BSA $0.5 \mathrm{mM}$, phosphate buffer $20 \mathrm{mM}$, and $\mathrm{pH} 7.4$, at $77 \mathrm{~K} .\left(\mathrm{b}^{\prime}\right)$ and $\left(c^{\prime}\right)$ are the simulated spectra of (b) and (c), using EasySpin [20] with parameters in Table 4.

Figure 6 displays the EPR spectra of $\mathrm{Cu}$ (II) $(0.5 \mathrm{mM})$ in the presence of equimolar amounts of HSA (a) and BSA (b). The spectra are characteristic of a superposition of two binding sites (hyperfine lines labeled 1 and 2 in the $g_{\|}$region, in Figure 6). The $g_{\perp}$ region is a superposition of the lines from both sites. It can be noticed that the HSA and BSA spectra are very similar. At $\mathrm{pH} 7.4$ both sites are occupied even at a 1:1 molar ratio, as already found by Patel and Pandeya [42]. The $\mathrm{Cu}(\mathrm{II})$-BSA EPR spectrum was simulated $\left(\mathrm{b}^{\prime}\right)$ using EasySpin [20] and the parameters appear in Table 4.

Figure 6 also shows the $\mathrm{Cu}(\mathrm{II})$-bipy and $\mathrm{Cu}(\mathrm{II})$-phen EPR spectra in the presence of equimolar amounts of HSA ((c) and (d)). The spectra of both complexes are very similar and also show a superposition of two binding sites. It can be noticed that the lines labeled 1 have the same positions in (c) and (d)

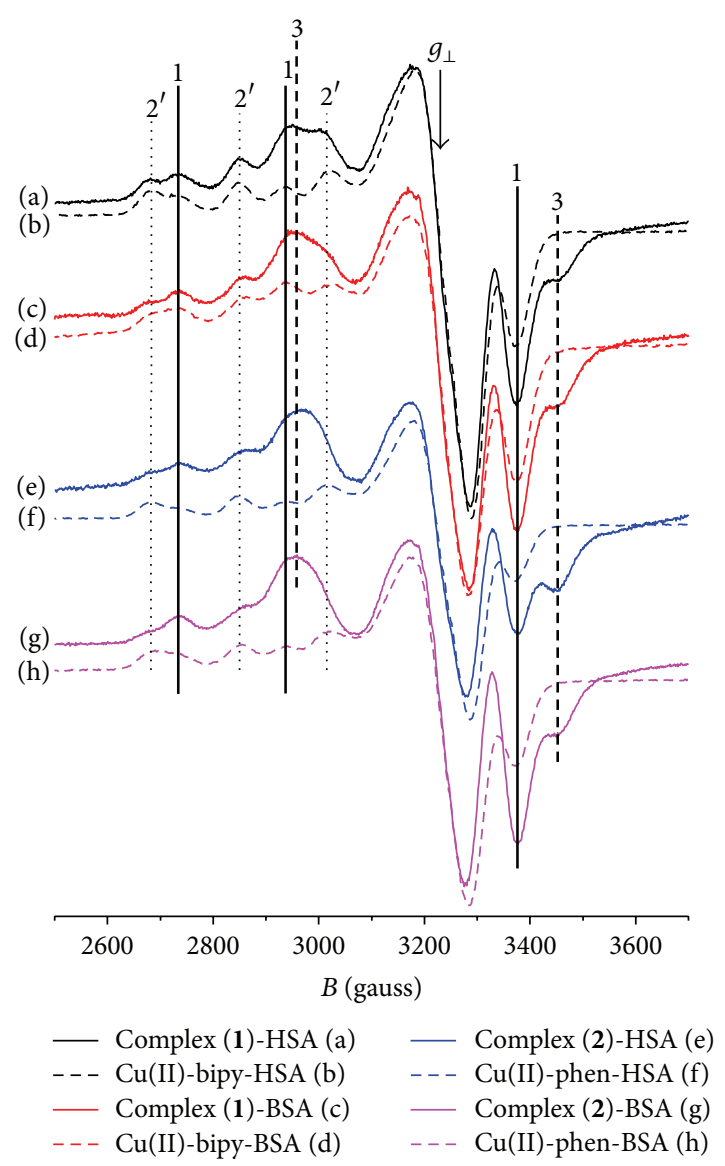

Figure 7: X-band EPR spectra for complexes 1, Cu(II)-bipy, 2, and $\mathrm{Cu}$ (II)-phen with equimolar amounts of HSA or BSA (concentration of the complexes: $0.5 \mathrm{mM}$, phosphate buffer $20 \mathrm{mM}, \mathrm{pH} 7.4$, and temperature $77 \mathrm{~K}$ ). (a) 1:HSA; (b) Cu(II)-bipy:HSA; (c) 1:BSA; (d) $\mathrm{Cu}$ (II)-bipy:BSA; (e) 2:HSA; (f) Cu(II)-phen:HSA; (g) 2:BSA; (h) $\mathrm{Cu}(\mathrm{II})$-phen:BSA.

as in (a) and (b), suggesting the same binding environment. This can be due to the displacement of the bipyridine and phenanthroline ligands by HSA to bind $\mathrm{Cu}(\mathrm{II})$ at the first site. The hyperfine lines of the second site (labeled $2^{\prime}$ ), however, are displaced to higher field values, indicating a $g_{\|}$shift to a lower value relative to $\mathrm{Cu}(\mathrm{II})$ site 2 . The EPR spectrum of $\mathrm{Cu}$ (bipy)(HSA) was also simulated $\left(c^{\prime}\right)$ using EasySpin [20] and the parameters for the two sites appear in Table 4. This analysis suggests formation of mixed-ligand complexes $\mathrm{Cu}$ (bipy)(HSA) and $\mathrm{Cu}$ (phen)(HSA) at this second site. The spectra ((c) and (d)) also show an increased population of site $2^{\prime}$ relative to site 1 , indicating a higher affinity of this site for the complexes rather than for the naked $\mathrm{Cu}(\mathrm{II})$ ions. Similar results were found for BSA (see Figure 7, (d) and (h)).

Figure 7 shows the EPR spectra obtained when HSA and BSA are added to solutions of the copper complexes at a molar ratio of $1: 1((\mathrm{a}),(\mathrm{c}),(\mathrm{e})$, and $(\mathrm{g}))$. It can be observed that a fraction of the binuclear complexes (lines labeled 3) dissociates and binds to the albumins as mononuclear complexes, presenting EPR spectra characteristic of a superposition of two $\mathrm{Cu}$ (II) binding sites (lines labeled 1 and $2^{\prime}$ ). 
Figure 7 also shows the respective EPR spectra of $\mathrm{Cu}(\mathrm{II})$ bipy and $\mathrm{Cu}(\mathrm{II})$-phen with HSA and BSA added at a 1:1 molar ratio ((b), (d), (f), and (h)). The lines of binuclear complexes (labeled 3) are absent in the absence of NOR, but the lines for the two sites appear at the same positions (see vertical lines labeled 1 and $2^{\prime}$ ) and have therefore similar EPR parameters. It is concluded that both $\mathrm{Cu}(\mathrm{II})$ sites in albumin compete with $\mathrm{NOR}$ for the $\mathrm{Cu}(\mathrm{II})$-bipy and $\mathrm{Cu}(\mathrm{II})$-phen complexes. Probably, mixed-ligand complexes $\mathrm{Cu}$ (bipy)(SA) and $\mathrm{Cu}$ (phen)(SA) are formed at site 2, where SA stands for serum albumin. Site 1 can probably displace the two ligands, since spectral parameters are the same as for $\mathrm{Cu}$ (II) ion.

Comparing every two complexes' spectra with and without NOR (Figure 7), it is noticed that components 1 and $2^{\prime}$ appear with different fractions. Site 1 component is greater in presence ((a), (c), (e), and (g)) than in absence of NOR ((b), (d), (f), and (h)). The presence of NOR shifts the equilibrium toward a larger population of site 1 . A possible explanation is that dissociated NOR molecules also bind to albumin near site 2 and compete with the complexes for this site.

Since the albumin molecules are not able to displace all the NOR molecules from the binuclear mixed-ligand complexes, one concludes that the association constants of both $\mathrm{Cu}(\mathrm{II})$-bipy and $\mathrm{Cu}(\mathrm{II})$-phen with the serum albumins are of the same order of magnitude as with NOR.

In the case of $T$. cruzi activity, similar results were observed for single and mixed-ligand complexes (see Table 2). This result suggests that $\mathrm{Cu}(\mathrm{II})$-bipy and $\mathrm{Cu}(\mathrm{II})$ phen were the main active species in these experiments. Based on the results demonstrating that the BSA and HSA $\mathrm{Cu}$ (II) sites compete with NOR for $\mathrm{Cu}(\mathrm{II})$-bipy and $\mathrm{Cu}(\mathrm{II})$ phen to form mixed-ligand complexes, it is reasonable to suggest that the important activity sites in T. cruzi can also displace NOR from the mixed complexes so that only $\mathrm{Cu}(\mathrm{II})$-bipy and $\mathrm{Cu}(\mathrm{II})$-phen bind to the relevant sites.

\section{Conclusions}

Two copper(II) complexes with norfloxacin in the presence of nitrogen donor heterocyclic ligand $2,2^{\prime}$-bipyridine or 1,10-phenantroline were obtained: the square pyramidal or trigonal bipyramidal $[\mathrm{CuCl}($ bipy $)(\mathrm{NOR})] \mathrm{Cl} \cdot 2 \mathrm{H}_{2} \mathrm{O}(\mathbf{1})$ and the octahedral $\left[\mathrm{CuCl}_{2}\right.$ (phen)(NOR)] $3 \mathrm{H}_{2} \mathrm{O}$ (2). In these complexes, norfloxacin is coordinated to $\mathrm{Cu}(\mathrm{II})$ through the carboxylato and ketone oxygen atoms.

The trypanocidal activity of the copper complexes was tested using bloodstream trypomastigotes. It was shown that $\left[\mathrm{CuCl}_{2}\right.$ (phen) $]$ and $\left[\mathrm{CuCl}_{2}\right.$ (phen)(NOR) $] \cdot 3 \mathrm{H}_{2} \mathrm{O}$ were the most active compounds. However, EPR interaction studies showed that BSA and HSA compete with NOR to form mixed-ligand complexes, and only $\mathrm{Cu}(\mathrm{II})$-phen binds to the relevant sites in these proteins. This suggests that $\mathrm{Cu}(\mathrm{II})$-phen was responsible for the anti-T. cruzi activity.

The fluorescence titration results revealed that low concentrations of the $\mathrm{Cu}$ (II) complexes do not interact with BSA and HSA near the Trp residues. In fact, the highest affinity copper site in BSA and HSA involves the first three residues at the $\mathrm{N}$-terminal, which is 31 to $35 \AA$ away from Trp214 in HSA (4LA0 in RCSB PDB) or Trp213 in BSA
(4F5S in RCSB PDB). The distance between the $\alpha$-carbons of Asp1 and Trp134 in BSA is even larger, $40 \AA$. However, in concentrations greater than about half of the albumins concentration, the interaction occurs at the albumins' second site. $K_{\mathrm{SV}}$ values, about $10^{4} \mathrm{~L} \mathrm{~mol}^{-1}$, indicated a moderated affinity of this albumin site for the complexes. The EPR results suggest that this site displaces NOR from the complex and only $\mathrm{Cu}(\mathrm{II})$-bipy and $\mathrm{Cu}(\mathrm{II})$-phen bind to the protein.

EPR studies of the albumin binding to the $\mathrm{Cu}(\mathrm{II})$ complexes showed that the association constants of both $\mathrm{Cu}(\mathrm{II})$ bipy and $\mathrm{Cu}(\mathrm{II})$-phen with the serum albumins were of the same order of magnitude as with NOR, since the albumin molecules were not able to displace all the NOR molecules from the binuclear mixed-ligand complexes.

\section{Conflict of Interests}

The authors declare that there is no conflict of interests regarding the publication of this paper.

\section{Acknowledgments}

The present study was supported by Fundação de Amparo a Pesquisa do Estado de Minas Gerais (FAPEMIG), Fundação Carlos Chagas Filho de Amparo a Pesquisa do Estado do Rio de Janeiro (FAPERJ), FIOCRUZ, and Conselho Nacional de Desenvolvimento Científico e Tecnológico (CNPq). The EPR spectrometer from Centro Brasileiro de Pesquisas Físicas (CBPF) was used in this research.

\section{References}

[1] L. C. Dias, M. A. Dessoy, J. J. Silva, O. H. Thiemann, G. Oliva, and A. D. Andricopulo, "Quimioterapia da doença de Chagas: estado da arte e perspectivas no desenvolvimento de novos fármacos," Química Nova, vol. 32, no. 9, pp. 2444-2457, 2009.

[2] M. N. C. Soeiro and S. L. de Castro, "Trypanosoma cruzi targets for new chemotherapeutic approaches," Expert Opinion on Therapeutic Targets, vol. 13, no. 1, pp. 105-121, 2009.

[3] P. C. Appelbaum and P. A. Hunter, "The fluoroquinolone antibacterials: past, present and future perspectives," International Journal of Antimicrobial Agents, vol. 16, no. 1, pp. 5-15, 2000.

[4] T. Fang, X. Li, C. Wang et al., "The action of norfloxacin complexes on Tetrahymena investigated by microcalorimetry," Journal of Thermal Analysis and Calorimetry, vol. 109, no. 1, pp. 433-439, 2012.

[5] C. Dendrinou-Samara, G. Psomas, C. P. Raptopoulou, and D. P. Kessissoglou, "Copper(II) complexes with phenoxyalkanoic acids and nitrogen donor heterocyclic ligands: structure and bioactivity," Journal of Inorganic Biochemistry, vol. 83, no. 1, pp. 7-16, 2001.

[6] E. K. Efthimiadou, N. Katsaros, A. Karaliota, and G. Psomas, "Mononuclear copper(II) complexes with quinolones and nitrogen-donor heterocyclic ligands: synthesis, characterization, biological activity and interaction with DNA," Inorganica Chimica Acta, vol. 360, no. 15, pp. 4093-4102, 2007.

[7] P. Ruíz, R. Ortiz, L. Perelló et al., "Synthesis, structure, and nuclease properties of several binary and ternary complexes of 
copper(II) with norfloxacin and 1,10 phenantroline," Journal of Inorganic Biochemistry, vol. 101, no. 5, pp. 831-840, 2007.

[8] E. K. Efthimiadou, H. Thomadaki, Y. Sanakis et al., "Structure and biological properties of the copper(II) complex with the quinolone antibacterial drug $N$-propyl-norfloxacin and $2,2^{\prime}$ bipyridine," Journal of Inorganic Biochemistry, vol. 101, no. 1, pp. 64-73, 2007.

[9] P. Živec, F. Perdih, I. Turel, G. Giester, and G. Psomas, "Different types of copper complexes with the quinolone antimicrobial drugs ofloxacin and norfloxacin: structure, DNA- and albuminbinding," Journal of Inorganic Biochemistry, vol. 117, pp. 35-47, 2012.

[10] S. Dorotíková, J. Kožíšková, M. Malček et al., "Copper(II) complexes with new fluoroquinolones: synthesis, structure, spectroscopic and theoretical study, DNA damage, cytotoxicity and antiviral activity," Journal of Inorganic Biochemistry, vol. 150, pp. 160-173, 2015.

[11] I. Turel, "The interactions of metal ions with quinolone antibacterial agents," Coordination Chemistry Reviews, vol. 232, no. 1-2, pp. 27-47, 2002.

[12] D. D. G. J. Batista, P. B. da Silva, L. Stivanin et al., "Co(II), Mn(II) and $\mathrm{Cu}$ (II) complexes of fluoroquinolones: synthesis, spectroscopical studies and biological evaluation against Trypanosoma cruzi," Polyhedron, vol. 30, no. 10, pp. 1718-1725, 2011.

[13] L. R. Gouvea, L. S. Garcia, D. R. Lachter et al., "Atypical fluoroquinolone gold(III) chelates as potential anticancer agents: relevance of DNA and protein interactions for their mechanism of action," European Journal of Medicinal Chemistry, vol. 55, pp. 67-73, 2012.

[14] D. A. Martins, L. R. Gouvea, D. G. J. Batista et al., “Copper(II)fluoroquinolone complexes with anti-Trypanosoma cruzi activity and DNA binding ability," BioMetals, vol. 25, no. 5, pp. 951960, 2012.

[15] I. Turel, J. Kljun, F. Perdih et al., "First ruthenium organometallic complex of antibacterial agent ofloxacin. Crystal structure and interactions with DNA," Inorganic Chemistry, vol. 49, no. 23, pp. 10750-10752, 2010.

[16] D. Silva, C. M. Cortez, and S. R. W. Louro, "Chlorpromazine interactions to sera albumins: a study by the quenching of fluorescence," Spectrochimica Acta Part A: Molecular and Biomolecular Spectroscopy, vol. 60, no. 5, pp. 1215-1223, 2004.

[17] M. Fasano, S. Curry, E. Terreno et al., "The extraordinary ligand binding properties of human serum albumin," IUBMB Life, vol. 57, no. 12, pp. 787-796, 2005.

[18] A. Bujacz, "Structures of bovine, equine and leporine serum albumin," Acta Crystallographica Section D: Biological Crystallography, vol. 68, no. 10, pp. 1278-1289, 2012.

[19] G. Zhang, N. Zhao, X. Hu, and J. Tian, "Interaction of alpinetin with bovine serum albumin: probing of the mechanism and binding site by spectroscopic methods," Spectrochimica Acta Part A: Molecular and Biomolecular Spectroscopy, vol. 76, no. 34, pp. 410-417, 2010.

[20] S. Stoll and A. Schweiger, "EasySpin, a comprehensive software package for spectral simulation and analysis in EPR," Journal of Magnetic Resonance, vol. 178, no. 1, pp. 42-55, 2006.

[21] M. N. L. de Meirelles, T. C. D. A. Jorge, and W. de Souza, "Interaction of Trypanosoma cruzi with macrophages in vitro: dissociation of the attachment and internalization phases by low temperature and cytochalasin B," Zeitschrift für Parasitenkunde, vol. 68 , no. 1, pp. 7-14, 1982.

[22] D. G. J. Batista, M. G. O. Pacheco, A. Kumar et al., "Biological, ultrastructural effect and subcellular localization of aromatic diamidines in Trypanosoma cruzi," Parasitology, vol. 137, no. 2, pp. 251-259, 2010.

[23] A. Daliry, P. B. Da Silva, C. F. Da Silva et al., "In vitro analyses of the effect of aromatic diamidines upon Trypanosoma cruzi," Journal of Antimicrobial Chemotherapy, vol. 64, no. 4, pp. 747750, 2009.

[24] M. N. Meirelles, T. C. de Araujo-Jorge, C. F. Miranda, W. de Souza, and H. S. Barbosa, "Interaction of Trypanosoma cruzi with heart muscle cells: ultrastructural and cytochemical analysis of endocytic vacuole formation and effect upon myogenesis in vitro," European Journal of Cell Biology, vol. 41, no. 2, pp. 198206, 1986.

[25] T. Mosmann, "Rapid colorimetric assay for cellular growth and survival: application to proliferation and cytotoxicity assays," Journal of Immunological Methods, vol. 65, no. 1-2, pp. 55-63, 1983.

[26] S. C. Wallis, L. R. Gahan, B. G. Charles, T. W. Hambley, and P. A. Duckworth, "Copper(II) complexes of the fluoroquinolone antimicrobial ciprofloxacin. Synthesis, X-ray structural characterization, and potentiometric study," Journal of Inorganic Biochemistry, vol. 62, no. 1, pp. 1-16, 1996.

[27] D. K. Saha, S. Padhye, C. E. Anson, and A. K. Powell, "Hydrothermal synthesis, crystal structure, spectroscopy, electrochemistry and antimycobacterial evaluation of the copper (II) ciprofloxacin complex: $\left[\mathrm{Cu}(\mathrm{cf})_{2}\left(\mathrm{BF}_{4}\right)_{2}\right] \cdot 6 \mathrm{H}_{2} \mathrm{O}$," Inorganic Chemistry Communications, vol. 5, no. 12, pp. 1022-1027, 2002.

[28] N. Jiménez-Garrido, L. Perelló, R. Ortiz et al., "Antibacterial studies, DNA oxidative cleavage, and crystal structures of $\mathrm{Cu}$ (II) and $\mathrm{Co}$ (II) complexes with two quinolone family members, ciprofloxacin and enoxacin," Journal of Inorganic Biochemistry, vol. 99, no. 3, pp. 677-689, 2005.

[29] E. K. Efthimiadou, Y. Sanakis, C. P. Raptopoulou, A. Karaliota, N. Katsaros, and G. Psomas, "Crystal structure, spectroscopic, and biological study of the copper(II) complex with thirdgeneration quinolone antibiotic sparfloxacin," Bioorganic of Medicinal Chemistry Letters, vol. 16, no. 14, pp. 3864-3867, 2006.

[30] G. B. Deacon and R. J. Phillips, "Relationships between the carbon-oxygen stretching frequencies of carboxylato complexes and the type of carboxylate coordination," Coordination Chemistry Reviews, vol. 33, no. 3, pp. 227-250, 1980.

[31] J. A. Weil, J. R. Bolton, and J. E. Wertz, Electron Paramagnetic Resonance: Elementary Theory and Practical Applications, John Wiley \& Sons, New York, NY, USA, 1993.

[32] L. J. Singh, N. S. Devi, S. P. Devi et al., "Spectroscopic studies on bis(1-amidino-O-alkylurea) copper(II) sulfate complexes where alkyl = methyl, ethyl, n-propyl or n-butyl: EPR evidence for binuclear complexes," Inorganic Chemistry Communications, vol. 13, no. 3, pp. 365-368, 2010.

[33] S. S. Eaton, K. M. More, B. M. Sawant, and G. R. Eaton, "Use of the ESR half-field transition to determine the interspin distance and the orientation of the interspin vector in systems with two unpaired electrons," Journal of the American Chemical Society, vol. 105, no. 22, pp. 6560-6567, 1983.

[34] D. K. Saha, U. Sandbhor, K. Shirisha et al., "A novel mixed-ligand antimycobacterial dimeric copper complex of ciprofloxacin and phenanthroline," Bioorganic \& Medicinal Chemistry Letters, vol. 14, no. 12, pp. 3027-3032, 2004.

[35] G. Psomas, A. Tarushi, E. K. Efthimiadou, Y. Sanakis, C. P. Raptopoulou, and N. Katsaros, "Synthesis, structure and biological activity of copper(II) complexes with oxolinic acid," Journal of Inorganic Biochemistry, vol. 100, no. 11, pp. 1764-1773, 2006. 
[36] J. R. Lakowicz, Principles of Fluorescence Spectroscopy, Springer, New York, NY, USA, 3rd edition, 2006.

[37] G. Rakhit, W. E. Antholine, W. Froncisz et al., "Direct evidence of nitrogen coupling in the copper(II) complex of bovine serum albumin by S-band electron spin resonance technique," Journal of Inorganic Biochemistry, vol. 25, no. 3, pp. 217-224, 1985.

[38] P. J. Sadler, A. Tucker, and J. H. Viles, "Involvement of a lysine residue in the $\mathrm{N}$-terminal $\mathrm{Ni}^{2+}$ and $\mathrm{Cu}^{2+}$ binding site of serum albumins. Comparison with $\mathrm{Co}^{2+}, \mathrm{Cd}^{2+}$ and $\mathrm{Al}^{3+}$, European Journal of Biochemistry, vol. 220, no. 1, pp. 193-200, 1994.

[39] A. Zgirski and E. Frieden, "Binding of $\mathrm{Cu}(\mathrm{II})$ to non-prosthetic sites in ceruloplasmin and bovine serum albumin," Journal of Inorganic Biochemistry, vol. 39, no. 2, pp. 137-148, 1990.

[40] S. Sugio, A. Kashima, S. Mochizuki, M. Noda, and K. Kobayashi, "Crystal structure of human serum albumin at 2.5 Å resolution," Protein Engineering, Design \& Selection, vol. 12, no. 6, pp. 439446, 1999.

[41] Y. Zhang and D. E. Wilcox, "Thermodynamic and spectroscopic study of $\mathrm{Cu}$ (II) and $\mathrm{Ni}(\mathrm{II})$ binding to bovine serum albumin," Journal of Biological Inorganic Chemistry, vol. 7, no. 3, pp. 327337, 2002.

[42] R. N. Patel and K. B. Pandeya, "X-band electron paramagnetic resonance spectra of pig serum albumin-copper(II) and pig serum albumin-copper(II)-amino acid systems," Indian Journal of Biochemistry \& Biophysics, vol. 37, no. 4, pp. 251-255, 2000. 

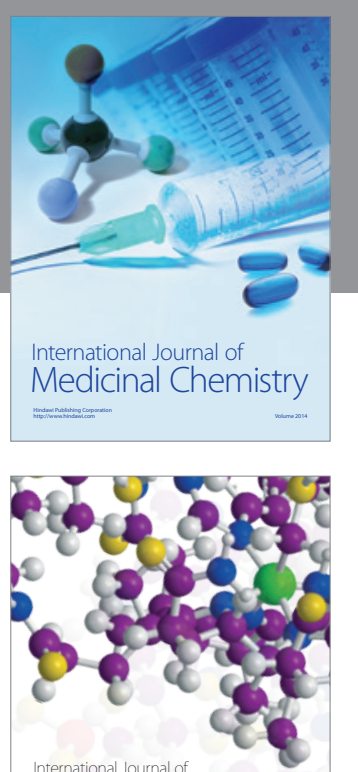

Carbohydrate Chemistry

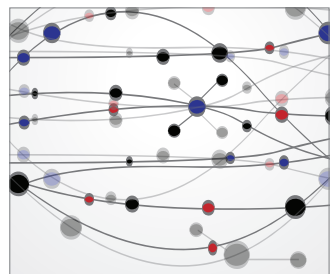

The Scientific World Journal
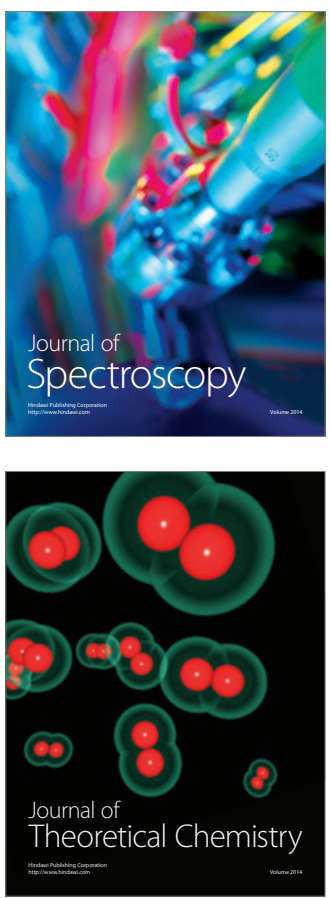
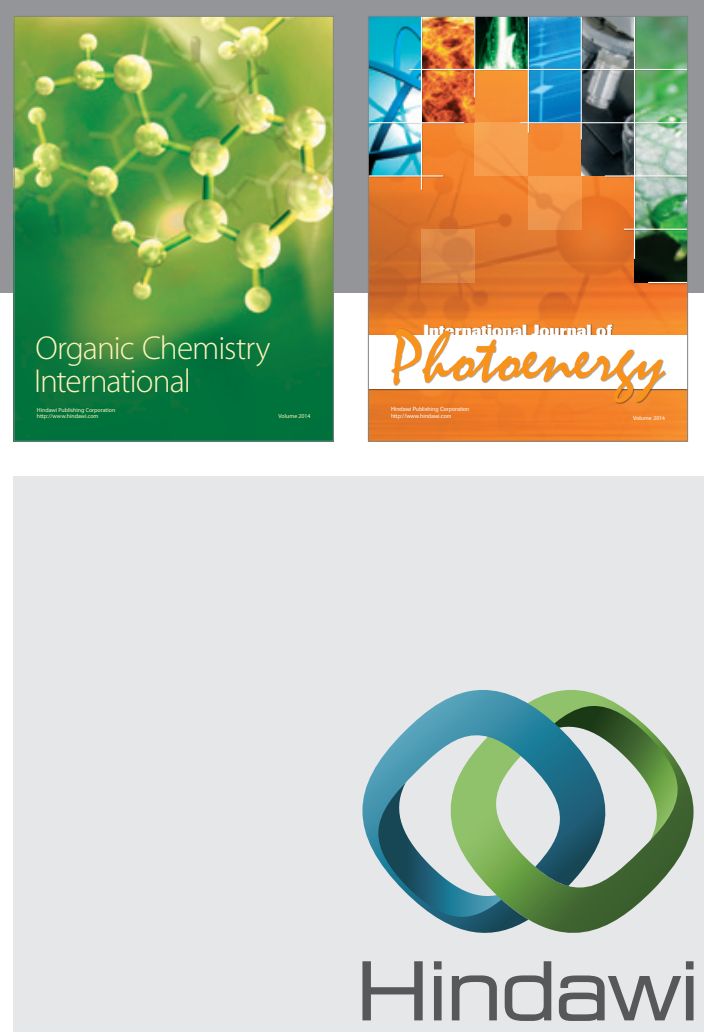

Submit your manuscripts at

http://www.hindawi.com

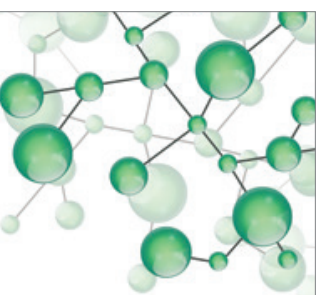

International Journal of

Inorganic Chemistry

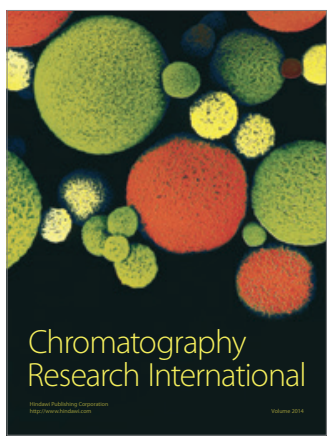

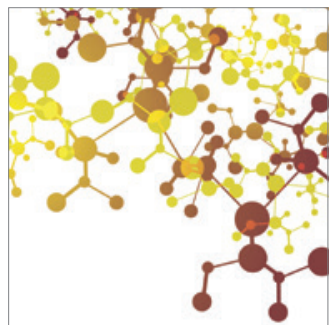

Applied Chemistry
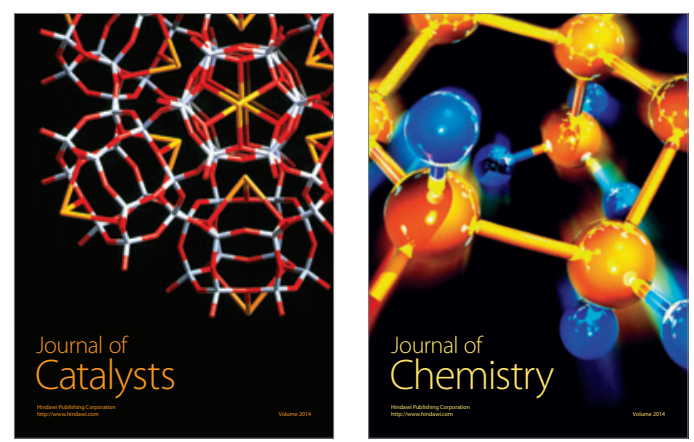
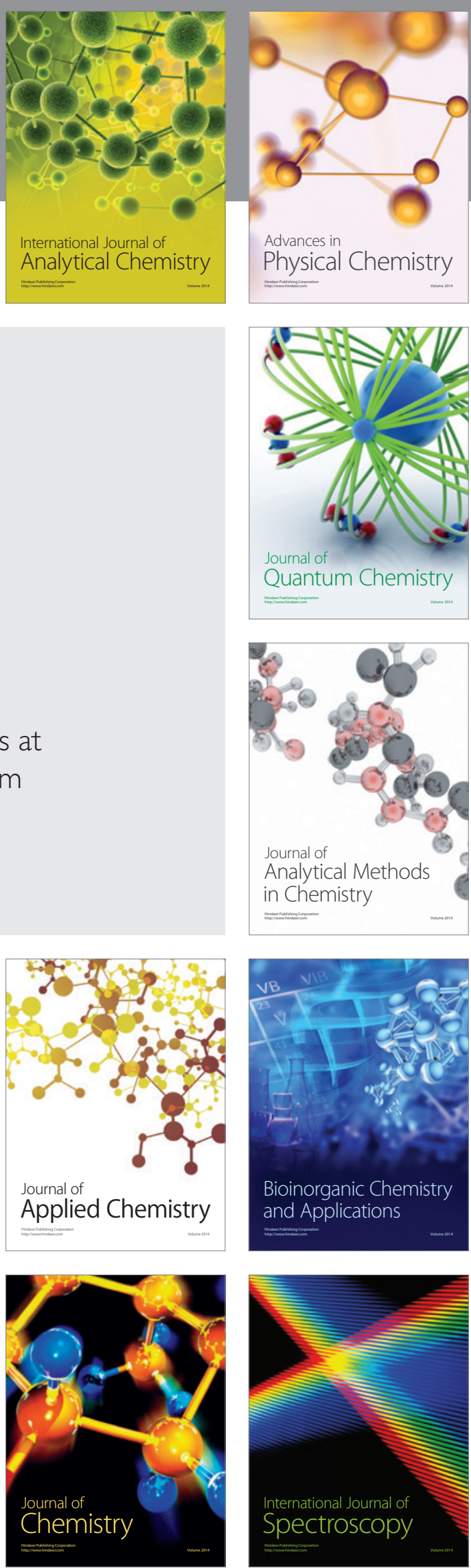